\title{
Pengaruh Citra Merek (Brand Image) Terhadap Keputusan Pembelian Kerudung Deenay (Studi pada Konsumen Gea Fashion Banjar)
}

\author{
Iis Miati ${ }^{\mathrm{a}, 1, *}$ \\ a STIA YPPT Priatim Tasikmalaya \\ 1 iismiati@stia-tasik.ac.id * \\ * corresponding author
}

\section{ARTICLE INFO}

\section{Article history}

Received

Revised

Accepted

Keywords

Brand,

Brand Image,

Purchase Decision

\begin{abstract}
The development of the economy at this time will cause very tight competition in the business field. The company will continue to develop its products by creating unique products that are different from competitors that produce similar products.

At this time consumers are fanatic in choosing a product, besides they want a quality product they will also choose a product that has a brand image that is quite good in the community.

Deenay veil products are currently a product that is favored by every society. At Gea Fashion Banjar deenay brand hood sales are higher each month compared to other brand hoods. Based on that, the writer is interested in researching the Effect of Brand Image on the Decision to Purchase Deenay Veil in Banjar Gea Fashion.

The purpose of this study was to determine how the influence of Brand Image on the Purchase Decision Deenay Veil on Banjar Gea Fashion?

The research method used is quantitative descriptive research method, with a sample of 50 people.

The results showed that brand image had a significant influence on the decision making for purchasing veil deenay. This significance value was obtained from Fcount 29,689 with a significance of 0,000 with $\mathrm{F}$ table (4.04) at the significance level of 0.05 and the coefficient of determination $\left(\mathrm{r}^{2}\right)$ or $\mathrm{R}$ square obtained by 0.328 , so that the magnitude of influence was $38.2 \%$, whereas the remaining $61.8 \%$ is influenced by other factors not included in this research variable.

In conclusion, consumers make purchasing decisions due to the influence of brand image and social, cultural, personal and psychological factors.
\end{abstract}

\section{PENDAHULUAN}

\section{Latar Belakang Penelitian}

Perekonomian pada zaman ini terus berkembang dan semakin mengarah pada persaingan yang sangat ketat terutama dalam bidang bisnis yang dilakukan oleh perusahaan yang memproduksi barang atau jasa yang sejenis. Untuk mempertahankan perusahaan maka perusahaan harus mengikuti perubahan baik dalam bidang ekonomi, politik, social dan budaya. Disamping itu perusahaan juga harus mengikuti cara atau metode competitor dalam menjalankan usahanya. Perusahaan harus mempunyai produk unik yang akan menarik perhatian konsumen.

Konsumen pada saat ini sangat selektif dalam memilih sebuah produk, sampai pada akhirnya mereka melakukan keputusan untuk membeli produk tersebut. Sebagaimana kita ketahui bahwa produk yang ditawarkan sangat beraneka ragam sesuai dengan trand saat ini. Konsumen akan memilih sebuah produk selain yang memiliki kualitas yang baik juga mereka akan memilih sebuah merek yang cukup terkenal atau mempunyai citra merek (brand image).

Sekarang ini salah satu produk yang sedang berkembang pesat adalah produk kerudung. Hal ini disebabkan karena masyarakat masa kini yang selalu mengikuti trand atau mode dalam berhijab. Dengan perilaku konsumen seperti ini maka peluang bagi perusahaan untuk mengeluarkan berbagai macam model, corak bahkan merek yang bervariatif dari perusahaan perusahaan sejenis. terus menerus bermunculan dalam 
iklan dimedia massa. Hal ini dilakukan oleh perusahaan untuk menarik minat konsumen untuk membeli produknya.

Produk kerudung saat ini sangat kompetitif baik dari bahan, warna dan kecanggihan teknologi serta merek. Merek -merek kerudung yang beredar dipasaran semakin banyak mulai dari harga yang murah sampai yang mahal. Dengan banyaknya produk kerudung yang beredar dipasaran maka akan memudahkan konsumen untuk memlih produk yang mereka inginkan sesuai dengan minat dan keadaan ekonominya.

Konsumen dalam melalukan keputusan pembelian sebuah produk mereka akan menilai terlebih dahulu kualitas dari produk tersebut. Produk barang yang berkualitas tentunya akan semakin banyak diminati oleh konsumen. Perusahaan akan terus bersaing untuk meningkatkan kualitas produknya dan mempertahan citra merek produk yang dimilikinya. Sebuah merek tentunya sudah mempunyai ciri khas masing-masing dalam memproduksi sebuah barang dan tentunya akan berbeda dengan produk yang lainnya.

Keputusan pembelian yang dilakukan konsumen ini melibatkan sebuah pemikiran terhadap kualitas, nilai dan harga. Namun konsumen tidak semata-mata akan membeli sebuah produk tanpa memikirkan manfaat dari produk yang dibelinya. Saat ini persepsi konsumen tentang sebuah produk yang mahal harganya sudah pasti kualitasnya bagus namun pada kenyataanya konsumen akan memilih sebuah produk yang memiliki sebuah citra merek dari sebuah produk.

Perusahaan akan terus melakukan berbagai upaya untuk mempertahankan citra merek (brand image) yang mereka miliki diantaranya inovasi teknologi keunggulan yang dimiliki produk tersebut, penetapan harga yang bersaing, dan melakukan promosi yang tepat sasaran.

Deenay merupakan merek kerudung yang sedang berkembang pesat saat ini, hal ini terlihat dari minat konsumen dalam melakukan pembelian produk ini. Hampir di seluruh Indonesia mulai dari perkotaan sampai ke daerah pedesaan masyarakat ramai mengenakan produk tersebut. Sepertinya persepsi masyarakat tentang merek deenay ini sudah bagus, karena deenay secara terus menerus melakukan inovasi baru dalam setiap pembuatan produk kerudungnya.

Sasaran konsumen Deenay kepada masyarakat umumnya wanita muslimah, mulai Mahasiswa, pegawai dan Ibu Rumah Tangga. Deenay mencitrakan dirinya sebagai kerudung yang berkkualitas sehingga cocok untuk berbagai kalangan masyarakat. Karena Citra Merek yang dibangun oleh Deenay tidak sedikit masyarakat yang menjadi pelanggan fanatik dari produk Deenay ini. Deenay berupaya untuk tetap menjaga citra mereknya dengan melakukan pomosi disosial media, dan mengadakan event-event.

Gea Fashion Banjar merupakan reseller deenay, selain menyediakan kerudung produk Deenay juga menyediakan produk-produk lainnya seperti Bee mee, Second Sign, Maliqa, Inji dan lain-lain. Namun dalam penjualannya produk Deenay paling diminati oleh konsumen. Berdasarkan observasi dilapangan diperoleh data penjualan kerudung deenay dapat terjual sebanyak 600 kerudung perbulannya, sedangkan kerudung merek lain hanya terjual 100 kerudung perbualannya.

Berdasarkan masalah diatas peneliti tertarik untuk mengambil judul penelitian Pengaruh Citra Merek (Brand Image) Terhadap Keputusan Pembelian Kerudung Deenay (Studi pada Konsumen Gea Fashion Banjar)

\section{Rumusan Masalah}

Berdasarkan uraian latar belakang yang telah di kemukakan, maka rumusan masalah dalam penulisan ini, adalah "Bagaimanakah pengaruh Citra Merek kerudung Deenay terhadap Keputusan Pembelian kerudung Deenay pada Gea Fashion Banjar?”

\section{Tujuan Penelitian}

Adapun tujuan dari penelitian ini adalah, untuk mengetahui bagaimana pengaruh Citra Merek terhadap keputusan pembelian kerudung Deenay pada Gea fashion Banjar.

\section{KAJIAN PUSTAKA, KERANGKA PEMIKIRAN DAN HIPOTESIS}

\section{Pengertian Merek}

Menurut (Kotler \&Keller,2012:263) dalam (Fatih Imantoro, 2018) merek adalah produk atau jasa yang dimensinya mendiferensiasikan merek tersebut dengan beberapa cara dari produk atau jasa lainnya 
yang dirancang untuk memuaskan kebutuhan yang sama. Perbedaan ini bisa fungsional, rasional dan nyata berhubungan dengan kinerja produk dari merek. Perbedaan ini bisa juga lebih bersifat simbolis, emosional, atau tidak nyata, berhubungan dengan apa yang dipresentasikan oleh merek.

Menurut Aaker (1991:2) dalam (Fatih Imantoro, 2018) menjelaskan bahwa merek adalah cara membedakan sebuah nama atau symbol seperti logo, trademark, atau desain kemasan yang dimaksudkan untuk mengidentifikasian produk atau jasa dari satu produsen atau satu kelompok produsen dan untuk membedakan produk atau jasa itu dari produsen pesaing. Adapun elemen dari merek adalah nama, symbol, logo, desain, dan kemasan. (Kotler \&Keller (2006:264) dalam (Fatih Imantoro, 2018).

Kotler dan Keller ( 2008;332) dalam (Halimah, 2015) menyebutkan merek menurut asosiasi Pemasaran Amerika dalam pada Jurnal menyatakan bahwa merek (brand) adalah nama, istilah, tanda, symbol atau rancangan atau kombinasi dari semuanya, yang dimaksudkan untuk mengidentifikasi barang atau jasa penjual dan untuk mendeferensiasikannya dari barang atau jasa pesaing.

Dari beberapa pengertian tentang merek diatas dapat disimpulkan bahwa merek merupakan salah satu cara perusahaan (produsen) memberikan nama, simbol barang maupun jasa yang diproduksinya untuk membuat konsumen mengenal dan mengingat produk yang dibuat oleh sebuah perusahaan.

\section{Citra Merek (Brand Image)}

Menurut Aaker,1994 dalam (Tingkir, 2014) menyebutkan citra merek merupakan serangkaian asosiasi yang ada dalam benak konsumen terhadap suatu merek, biasanya terorganisasi menjadi suatu makna. Citra Merek juga dikatakan sebagai penglihatan dan kepercayaan yang terpendam dibenak konsumen sebagai cerminan asosiasi yang tertahan diigatan konsumen (Kotler,2008).

Kemudian (Sutisna, 2003:83) dalam (Dedhy Pradana, 2017) menyatakan bahwa citra merek merupakan keseluruhan persepsi terhadap produk atau merek yang dibentuk dari informasi dan pengalaman masa lalu terhadap produk atau merek itu.

Selain itu (Dedhy Pradana, 2017) juga menyebutkan definisi lain dari citra merek adalah kesan yang diperoleh sesuai dengan pemahaman seseorang tentang sesuatu. (Alma, 2004:375) Citra merek (brand image) merupakan serangkaian asosiasi yang ada dalam benak konsumen terhadap suatu merek. Hubungan terhadap suatu merek akan semakin kuat jika berdasarkan pengalaman dan berbagai informasi.

Berdasarkan pengertian diatas maka dapat disimpulkan bahwa citra merek merupakan sebuah pemikiran yang ada didalam benak masyarakat tentang suatu barang atau jasa yang telah mereka kenal dan telah mereka gunakan atau dikonsumsi. Dimana konsumen akan mengingat kekurangan dan kelebihan dari barang yang telah mereka gunakan tersebut.

Kemudian (Dedhy Pradana, 2017) mendefinisikan citra merek menurut Tjiptono (2005:49) adalah deskripsi tentang asosiasi dan keyakinan konsumen terhadap merek tertentu.

Dalam (Dedhy Pradana, 2017) Menurut Low dan Lamb (2000:4) indikator citra merek adalah sebagai berikut:

a) Merek dikenal oleh masyarakat luas.

b) Merek menambah citra diri penggunanya.

c) Merek memiliki ciri khas yang berbeda dengan merek lain. kategori:

(Kotler 2008) dalam (Tingkir, 2014) menyatakan bahwa citra merek dapat diukur melalui tiga

1) Keuntungan dari asosiasi merek (favorability of brand association), suatu merek menciptakan sikap yang positif jika atribut dan manfaat merek tersebut dapat memuaskan kebutuhan dan keinginan konsumen

2) Kekuatan dari asosiasi merek (strength of brand association), asosiasi yang terbentuk dari informasi yang masuk kedalam ingatan konsumen dan bagaimana informasi tersebut bertahan sebagai bagian dari brand image

3) Keunikan dari asosiasi merek (uniqueness of brand association), merek yang unik dan menarik mampu menimbulkan asosiasi yang kuat didalam pikiran pelanggan. 
Menurut Kotler dan Keller (2008:346) dalam (Halimah, 2015) citra merek adalah persepsi dan keyakinan yang dilakukan oleh konsumen, seperti yang tercermin dalam asosiasi yang terjadi dalam memori konsumen. Rahman (2010:176) dalam (Halimah, 2015) mengemukakan brand image adalah citra atas suatu merek yang tujuannya menciptakan kecenderungan bagi konsumen atas merek tersebut.

Menurut Bilson Simamora (2003:37) dalam (Fristiana, 2012) mengungkapkan bahwa merek memiliki image (brand image) dan untuk memudahkan deskripsi image, konsumen melakukan asosiasi merek. Asosiasi merek adalah sesuatu yang berkaitan dengan ingatan mengenai sebuah merek. Asosiasi ini tidak hanya ada tetapi mempunyai sebuah kekuatan. (A.B. susanto \&Himawan Wijanarko,2004:132).

Merek yang kuat dapat menarik konsumen untuk menggunakannya sebagai factor penentu dalam pemilihan keputusan pembelian, sedangkan syarat yang kuat adalah citra merek (brand image). Citra merek merupakan interprestasi akumulasi sebagai informasi yang diterima konsumen. Yang menginterprestasikan adalah konsumen dan yang dinterprestasikan adalah informasi. Hasil interprestasi bergantung pada dua hal, pertama, bagaimana konsumen melakukan interprestasi dan kedua informasi apa yang diinterprestasikan. (Bilson Simamora, 2003:92) dalam (Fristiana, 2012)

Dari berbagai pernyataan tentang citra merek diatas, maka penulis menyimpulkan bahwa citra merek merupakan sebuah bentuk kepercayaan konsumen kepada suatu produk baik barang maupun jasa, citra merek tersebut akan ada dalam ingatan konsumen berdasarkan pengalaman dalam menggunakan sebuah produk akan menimbulkan sebuah kepercayaan bagi konsumen untuk terus menggunakan produk dengan merek tertentu dan dapat mempengaruhi orang lain atau lingkungannya untuk menggunakan produk dengan citra merek tersebut.

\section{Keputusan Pembelian}

Menurut Kotler dan Amstrong (2008:181) dalam (Dedhy Pradana, 2017) mengemukakan bahwa keputusan pembelian konsumen adalah membeli merek yang paling disukai.

Menurut Kotler dan Keller (2009:240) menyatakan keputusan pembelian adalah keputusan konsumen mengenai preferensi atas merek-merek yang ada di dalam kumpulan pilihan.

Menurut Kotler dalam Angio (2013;7) yang dinyatakan oleh (Halimah, 2015) keputusan pembelian adalah suatu tindakan konsumen untuk membentuk referensi diantara merek-merek dalam kelompok pilihan dan membeli produk yang paling disukai.

Berdasarkan teori diatas dapat di artikan bahwa keputusan pembelian merupakan sebuah tindakan konsumen untuk membeli sebuah barang yang mereka inginkan berdasarkan kualitas produknya atau merek sebuah produk.

Kemudian Kotler dan Armstrong (2008:181) dalam (Dedhy Pradana, 2017) meyebutkan indikator keputusan pembelian adalah sebagai berikut:

a) Kemantapan membeli setelah mengetahui informasi produk.

b) Memutuskan membeli karena merek yang paling disukai.

c) Membeli karena sesuai dengan keinginan dan kebutuhan.

d) Membeli karena mendapat rekomendasidari orang lain.

Selanjutnya menurut Suharno (2010:96) dalam (Fatih Imantoro, 2018) menyatakan keputusan pembelian adalah tahap dimana pembeli telah menentukan pilihannya dan melakukan pembelian produk, serta mengkonsumsinya. Hal ini berkaitan dalam usahanya memenuhi kebutuhan dengan tahap yangdilibatkan dalam mengevaluasi, memperoleh dan menggunakan produk. Terdapat empat factor yang mempengaruhi perilaku konsumen dalam melakukan pembelian, yaitu sebagai berikut:

1) Faktor Budaya, factor budaya seseorang mempengaruhi perilaku mereka dalam mencari, menyelesaikan dan mengkonsumsi suatu produk, secara mendalam dan konsisten.

2) Faktor Sosial, merupakan factor yang mempengaruhi perilaku konsumen yang terbentuk dan berasal dari lingkungan sekitar. Aktivitas sosialisasi seseorang dengan orang-orang disekelilingnya sehari-hari akan membentuk pola perilaku yang khas pada masyarakat.

3) Faktor Pribadi, factor pribadi yang mempengaruhi perilaku pembelian adalah usia dan tahap siklus hidup, pekerjaan, situasi ekonomi, gaya hidup dan personalitas 
4) Faktor Psikologis, factor psikologis merupakan factor dari dalam diri seseorang dan menentukan bagaimana mereka memilih dan mengkonsumsi produk. Pemasar perlu memahami factor psikologis, yang terdiri dari motivasi, persepsi, pembelajaran, dan keyakinan dan sikap.

Kemudian Fandy Tjiptono (2002:22) dalam (Fristiana, 2012) menyebutkan perilaku konsumen merupakan tindakan yang secara langsung terlibat dalam usaha memperoleh, menentukan produk dan jasa, tremasuk proses pengambilan keputusan yang mendahului dan mengikuti tindakan-tindakan tersebut. Dari pengertian ini dapat diketahui bahwa pemahaman terhadap perilaku konsumen bukanlah pekerjaan yang mudah, tetapi cukup sulit dan kompleks, khususnya disebabkan oleh banyaknya variable yang mempengaruhi dan variable-variabel tersebut cenderung saling berinetraksi.

Tahap-tahap proses keputusan pembelian menurut Philip Kotler (2008:179) dalam (Fristiana, 2012) adalah sebagai berikut:

1. Pengenalan masalah proses pembelian dimulai dengan pengenalan masalah atau kebutuhan. Kebutuhan itu dapat digerakkan oleh rangsangan dari dalam atau dari luar pembeli

2. Pencarian informasi konsumen dapat memperoleh informasi dari berbagai sumber, meliputi:

a. Sumber pribadi: keluarga, teman, tetangga, kenalan

b. Sumber komersil: iklan, tenaga penjual, penyalur, kemasan, pameran

c. Sumber public: media massa, organisasi konsumen

d. Sumber eksperensal: pernah menangani, menguji dan menggunakan produk tersebut

3. Evaluasi alternative dalam tahap ini tidak ada sustu proses evaluasi yang mudah dan tunggal yang dapat dpergunakan untuk semua konsumen atau bahkan oleh seorang konsumen dalam semua situasi pembeliannya

4. Keputusan pembelian, tahap ini diawali dengan tahap penilaian berbagai alternative yang dapat dilihat dari atribut-atribut yang melekat pada produk itu. Dengan indikasi itu konsumen membentuk pilihan. Namun ada dua factor yang mempengaruhi pada saat memilih, yaitu sikap pada orang lain dan kejelekan suatu produk

5. Perilaku setelah pembelian, setelah membeli suatu produk, konsumen akan mengalami beberapa tingkat kepuasan atau ketidakpuasan.

Berdasarkan teori-teori diatas dapat disimpulkan bahwa konsumen dapat melakukan keputusan pembelian suatu produk dapat dipengaruhi oleh pengalaman dan kepuasan pribadinya tentang sebuah produk, bisa juga berdasarkan informasi yang diperoleh dari lingkungan sekitar baik keluarga maupun teman, serta dapat melakukan pembelian berdasarkan budaya dan gaya hidup konsumen itu sendiri.

\section{Kerangka Pemikiran}

Kerangka pemikiran merupakan sebuah model konseptual mengenai bagimana seseorang berteori mengenai hubungan-hubungan antara beberapa factor atau konsep untuk menjawab masalah penelitian (Sekaran, 2003) dalam (Zulganef, 2013).

\section{Citra Merek :}

1. Keunggulan Asosiasi Merek

2. Kekuatan Asosiasi Merek

3. Keunikan Merek

\section{Keputusan Pembelian}

1. Faktor Budaya

2. Faktor Sosial

3. Factor Pribadi

4. Faktor Psikologis 


\section{Hipotesis}

Menurut (Sugiyono, 2014) hipotesis merupakan jawaban sementara terhadap rumusan masalah penelitian, dimana rumusan masalah penelitian telah dinyatakan dalam bentuk pertanyaan.

Berdasarkan tinjauan pustaka dan kerangka pemikiran maka hipotesis dalam penelitian ini adalah "ada pengaruh citra merek kerudung deenay terhadap keputusan pembelian kerudung deenay pada Gea Fashion Banjar"

\section{OBJEK DAN METODE PENELITIAN}

\section{Objek Penelitian}

Untuk mengetahui pengaruh citra merek (brand image) terhadap keputusan pembelian kerudung deenay objek penelitian ini dilaksanakan di Toko Gea Bags Kota Banjar, jalan kapten jamhur no.100 Kota Banjar.

\section{Metode Penelitian}

Penelitian ini diarahkan untuk mengetahui pengaruh citra merek (brand image) terhadap keputusan pembelian kerudung deenay objek penelitian ini dilaksanakan di Toko Gea Bags Kota Banjar.

Penelitian ini menggunakan metode deskriptif analisis yaitu melakukan penelitian terhadap kenyataankenyataan yang tengah berlangsung yang merupakan suatu masalah yang harus segera diatasi. Sejalan dengan pendapat Surahmad (1982 : 139) bahwa pada umumnya persamaan sifat dan segala bentuk penyelidikan deskriptif ini menuturkan dan menafsirkan data yang ada, seperti situasi yang dialami, hubungan kegiatan dan pandangan terhadap proses yang sedang terjadi.

\section{Variabel Penelitian}

Variabel penelitian ini terdiri dari : Citra merek (brand image) (X), dan Keputusan Pembelian (Y).

1. Variabel Citra Merek (X) yaitu merupakan Faktor-faktor citra merek

2. Variabel Keputusan Pembelian (Y) artinya unsur-unsur keputusan pembelian

\section{Populasi Responden}

Populasi dalam penelitian adalah subjek (misalnya manusia, klien) yang memenuhi kriteria yang ditetapkan, menurut sastroasmoro \& Ismail (1995) dalam Nursalam (2013) populasi dibagi menjadi dua bagian yakni populasi target dan populasi terjangkau. Populasi target adalah populasi yang memenuhi criteria sampling dan menjadi sasaran akhir penelitian sedangkan populasi terjangkau adalah populasi yang memenuhi criteria peneltian dan biasanya dapat dijangkau oleh peneliti dari kelompoknya.

Adapun yang menjadi populasi dalam penelitian ini adalah konsumen Toko Gea Bags sebanyak 50 orang.

\section{HASIL PENELITIAN DAN PEMBAHASAN}

\section{Hasil Penelitian}

Penulis melakukan penelitian ini bermaksud untuk menganalisis pengaruh citra merek (brand image) Kerudung Deenay terhadap pengambilan keputusan pembelian Kerudung Deenay pada Toko Gea Fashion Banjar. Adapun deskripsi hasil penelitian masing-masing variable dapat diuraikan sebagai berikut :

\section{Variabel Citra Merek (Brand Image)}

\section{Keunggulan Asosiasi Merek}

Faktor keunggulan asosiasi merek dapat digambarkan melalui table distribusi sebagai berikut:

Tabel 4.1

Distribusi Frekuensi Keunggulan Asosiasi Merek

\begin{tabular}{|c|c|c|c|c|}
\hline No & Interval & Kategori & Frekuensi & $\%$ \\
\hline 1 & $>15$ & Tinggi & 27 & 54,0 \\
\hline 2 & $10-15$ & Sedang & 23 & 46,0 \\
\hline 3 & $<10$ & Rendah & 0 & 0 \\
\hline \multicolumn{2}{|c|}{ Jumlah } & 50 & 100 \\
\hline
\end{tabular}


Berdasarkan table tersebutmenunjukkan bahwa dari 50 responden terdapat 27 responden dengan kategori tinggi (54\%), dan 23 responden dengan kategori sedang (46\%), serta 0 responden dengan kategori rendah $(0 \%)$.

Faktor keunggulan asosiasi merek yang berada pada kategori tinggi, hal tersebut dapat diartikan bahwa responden menyatakan bahwa merek deenay mempunyai kualitas yang baik dan dibuat dengan bahan yang baik sehingga hal tersebut dapat membuat orang lebih percaya. Dengan menggunakan kerudung deenay orang merasa nyaman dan lebih percaya diri. Sedangkan yang kategori sedang dapat diartikan bahwa responden menyatakan citra merek deenay cukup baik.

\section{Kekuatan Asosisi Merek}

Faktor kekuatan asosiasi merek dapat gambarkan melalui table distribusi sebagai berikut:

Tabel 4.2

Distribusi Frekuensi Kekuatan Asosiasi Merek

\begin{tabular}{|c|c|c|c|c|}
\hline No & Interval & Kategori & Frekuensi & $\%$ \\
\hline 1 & $>15$ & Tinggi & 23 & 46,0 \\
\hline 2 & $10-15$ & Sedang & 27 & 54,0 \\
\hline 3 & $<10$ & Rendah & 0 & 0 \\
\hline \multicolumn{2}{|c|}{ Jumlah } & 50 & 100 \\
\hline
\end{tabular}

Berdasarkan table tersebut dapat dipeoleh penjelasan bahwa dari 50 responden terdapat 23 responden dengan kategori tinggi (46\%), dan 27 responden dengan kategori sedang (54\%) serta 0 responden dengan kategori rendah $(0 \%)$.

Pada factor kekuatan asosiasi merek yang berkategori tinggi dapat diartikan bahwa responden mengganggap kerudung merek deenay dibuat dengan teknologi yang canggih, dan inovasinya yang terus berkembang. Responden dengan kategori sedang, hal ini dapat diartikan bahwa responden mneyatakan merek Deenay diprosuksi sesuai perkembangan jaman, tetapi inovasi yang digunakan masih ada beberapa orang yang kurang menyukai, hal ini terjadi karena selera dati setiap orang itu berbeda-beda dalam memilih produk kerudung.

\section{Keunikan Asosiasi Merek}

Faktor keunikan asosiasi merek dapat digambarkan melalui table distribusi frekuensi sebagai berikut:

Tabel 4.3

Distribusi Frekuensi Kekuatan Asosiasi Merek

\begin{tabular}{|c|c|c|c|c|}
\hline No & Interval & Kategori & Frekuensi & $\%$ \\
\hline 1 & $>18$ & Tinggi & 8 & 16,0 \\
\hline 2 & $12-18$ & Sedang & 40 & 80,0 \\
\hline 3 & $<12$ & Rendah & 2 & $4 \%$ \\
\hline \multicolumn{2}{|c|}{ Jumlah } & 50 & 100 \\
\hline
\end{tabular}

Berdasarkan table tersebut diatas dapat diperoleh penjelasan bahwa dari 50 responden terdapat 8 responden dengan kategori tinggi (16\%), dan 42 responden dengan kategori sedang (84\%) dan 2 responden dengan kategori rendah (4\%).

Pada factor keunikan asosiasi merek sebagain besar berkategori sedang, hal ini diartikan bahwa merek deenay mempnyau image yang baik terutama pada Gea Fashion Banjar. Merek deenay mempunyai keunikan dan jenis model atau corak yang bermacam-macam yang membuat konsumen lebih bebas untuk memlih model dan corak yang diinginkan. Sedangkan responden yang berkategori rendah hal ini disebabkan karena harga jula kerudung merek deenay itu mahal yang memnyebabkan tidak semua orang dapat membeli kerudung merek deenay.

\section{Hasil Penelitian Citra Merek}

Hasil perhitungan data variable citra merek (brand image) Kerudung Deenay pada toko Gea Fashion Banjar dari responden sebanyak 50 orang diperoleh, rata-rata (mean) $=48,42$, median sebesar $=47$, modus sebesar $=56$, standart deviasi $=7,22$. 


\section{Tabel 4.4}

Distribusi Frekuensi Citra Merek (Brand Image)

\begin{tabular}{|c|c|c|c|c|}
\hline No & Interval & Kategori & Frekuensi & $\%$ \\
\hline 1 & $>48$ & Tinggi & 21 & 42 \\
\hline 2 & $32-48$ & Sedang & 29 & 58 \\
\hline 3 & $<32$ & Rendah & 0 & 0 \\
\hline \multicolumn{2}{|c|}{ Jumlah } & 50 & 100 \\
\hline
\end{tabular}

Berdasarkan tabel tersebut menunjukkan bahwa dari 50 orang responden terdapat 21 responden dengan kategori tinggi (42\%), artinya responden tersebut mempunyai kepercayaan yang tinggi terhadap citra merek Deenay. Merek Deenay dianggap sebagai merek yang bagus dibandingkan dengan merek yang lainnya, karena merek Deenay dianggap mempunyai keunngulan dalam kualitas dan kredibiltas sehingga dapat menambah rasa percaya diri seseorang.

Kemudian terdapat 29 orang responden dengan kategori sedang (58\%) yang termasuk pada artinya bahwa responden menyatakan bahwa merek deenay mempunyai citra yang cukup. Hal ini dikarenakan beberapa responden menyatakan menggunakan merek lain selain deenay. Kerudung merek deenay harganya mahal sehingga beberepa orang tidak memilih merek deenay dan memilih merek lain. Kesimpulannya dari 50 orang responden hampir sebagain menyukai citra merek deenay tersebut.

\section{Variabel Keputusan Pembelian}

Unsur-unsur Keputusan Pembelian

\section{Faktor Kebudayaan}

Faktor Kebudayaan dapat digambarkan melalui table distribusi frekuensi sebagai berikut:

Tabel 4.5

Distribusi Frekuensi Faktor Kebudayaan

\begin{tabular}{|c|c|c|c|c|}
\hline No & Interval & Kategori & $\mathrm{F}$ & $\%$ \\
\hline 1 & $>12$ & Tinggi & 14 & 28,0 \\
\hline 2 & $8-12$ & Sedang & 34 & 68,0 \\
\hline 3 & $<8$ & Rendah & 2 & 4,0 \\
\hline \multicolumn{3}{|c|}{ Jumlah } & 50 & 100 \\
\hline
\end{tabular}

Berdasarkan table tersebut diatas dapat diperoleh penjelasan bahwa dari 50 responden terdapat 14 responden dengan kategori tinggi (28\%), 34 responden dengan kategori sedang (68\%) dan 2 responden dengan kategori rendah (4\%).

Pada factor kebudayaan sebagian besar berkategori sedang dan tinggi, hal ini dapat diartikan bahwa masyarakat dalam mengambil keputusan pembelian sangat terpengaruh oleh budaya disekitar mereka, ketika mereka menganggap bahwa citra merek merupakan sebagai gambaran dari strata social yang ada dilingkungannya, sehingga masyarakat memilih untuk membeli kerudung deenay.

\section{Faktor Sosial}

Faktor Sosial dalam variable keputusan pembelian dapat digambarkan melalui table distribusi frekuensi sebagai berikut:

Tabel 4.6

Distribusi Frekuensi Faktor Sosial

\begin{tabular}{|c|c|c|c|c|}
\hline No & Interval & Kategori & Frekuensi & $\%$ \\
\hline 1 & $>18$ & Tinggi & 10 & 20,0 \\
\hline 2 & $8-18$ & Sedang & 40 & 80,0 \\
\hline 3 & $<12$ & Rendah & 0 & 0,0 \\
\hline \multicolumn{2}{|r|}{ Jumlah } & 50 & 100 \\
\hline
\end{tabular}

Berdasarkan tabel diatas menunjukkan bahwa dari 50 responden terdapat 10 responden dengan kategori tinggi (20\%), dan 40 responden dengan kategori sedang $(80 \%)$ dan 0 responden dengan kategori rendah $(0 \%)$. 
Keputusan pembelian yang disebabkan oleh factor social sebagain besar berkategori sedang dan tinggi, hal ini dapat diartikan bahwa keputusan pembelian kerudung deenay disebabkan oleh pengaruh lingkungan dan keluarga. Dalam hal ini komunitas-komunitas muslimah dimasyarakat yang sebagian besar adalah mereka wanita yang mengerti akan mode, pekembangan jaman dan konsumstif. Komunitaskomunitas wanita muslimah ini biasanya menggunakan kerudung yang berkualitas, sehingga berkat dorongan darikomunitas dan teman makan responden banyak yang memutuskan untuk membeli kerudung merek deenay.

\section{Faktor Pribadi}

Faktor Pribadi dalam variable keputusan pembelian dapat digambarkan melalui table distribusi frekuensi sebagai berikut:

\section{Tabel 4.7}

Distribusi Frekuensi Faktor Pribadi

\begin{tabular}{|c|c|c|c|c|}
\hline No & Interval & Kategori & Frekuensi & $\%$ \\
\hline 1 & $>15$ & Tinggi & 20 & 40,0 \\
\hline 2 & $10-15$ & Sedang & 30 & 60,0 \\
\hline 3 & $<10$ & Rendah & 0 & 0,0 \\
\hline \multicolumn{2}{|r|}{ Jumlah } & 50 & 100 \\
\hline
\end{tabular}

Berdasarkan table diatas dapat diperoleh gambaran bahwa dari 50 responden terdapat 20 responden dengan kategori tinggi (40\%), dan 30 responden dengan kategori sedang $(60 \%)$ dan 0 responden dengan kategori rendah $(0 \%)$.

Keputusan pembelian yang disebabkan oleh factor pribadi sebagian besar berkategori sedang dan tinggi, hal ini dapat diartikan bahwa keputusan pembelian yang dilakukan oleh masyarakat dalam membei kerudung merek deenay diakrenakan responden mempunyai gaya hidup yang dianggap cukup mewah, hal ini dapt dilihat dari kerudung deenay yang merupakan kerudung yang harga jualnya yang tinggi, sehingga sebagain masyarakat akan dianggap mempunyai ekonomi yang lebih ketika mereka mampu membeli kerudung merek deenay.

\section{Faktor Psikologi}

Faktor Pribadi dalam variable keputusan pembelian dapat digambarkan melalui table distribusi frekuensi sebagai berikut:

Tabel 4.8

Distribusi Frekuensi Faktor Psikologi

\begin{tabular}{|c|c|c|c|c|}
\hline No & Interval & Kategori & Frekuensi & $\%$ \\
\hline 1 & $>10$ & Tinggi & 20 & 40,0 \\
\hline 2 & $7-10$ & Sedang & 25 & 50,0 \\
\hline 3 & $<7$ & Rendah & 5 & 10,0 \\
\hline \multicolumn{2}{|c|}{ Jumlah } & 50 & 100 \\
\hline
\end{tabular}

Berdasarkan table diatas dapat diperoelh penjelasan bahwa dari 50 responden terdapat 20 responden dengan kategori tinggi (40\%), 25 orang responden dengan kategori sedang (50\%) dan 5 responden dengan kategori rendah $(10 \%)$.

Pada factor psikologi sebagian besar berkategori sedang dan tinggi, hal ini dapat diperoleh kesimpulan bahwa dalam pengambilan keputusan untuk membeli kerudung deenay sebagian masyarakat dikarenakan dengan memakai kerudung deenay dapat menambah rasa percaya diri, karena masyarakat sudah menganggap bahwa kerudung deenay merupakan kerudung yang kualitasnya bagus meskipun harganya mahal. Karena sebagian masyarakat beranggapan dengan produk yang mahal pasti kualitasnya bagus dan mereka akan sangat menumbuhkan rasa percaya diri yang tinggi.

\section{Hasil Penelitian Keputusan Pembelian}

Hasil perhitungan keputusan pembelian kerudung deenay pada took Gea Fashion Banjar rata-rata (mean $)=51,28$, median $=50$, modus sebesar $=50$, standar deviasi $=7,91$. Untuk lebih jelas dapat dilihat dari table distribusi data keputusan pembelian sebagai berikut: 


\section{Tabel 4.9}

Distribusi Frekuensi Keputusan Pembelian Kerudung Deenay

\begin{tabular}{|c|c|c|c|c|}
\hline No & Interval & Kategori & Frekuensi & $\%$ \\
\hline 1 & $>55$ & Tinggi & 16 & 32 \\
\hline 2 & $38-55$ & Sedang & 32 & 64 \\
\hline 3 & $<38$ & Rendah & 2 & $4 \%$ \\
\hline \multicolumn{2}{|c|}{ Jumlah } & 50 & 100 \\
\hline
\end{tabular}

Berdasarkan table tersebut diatas, dapat diperoleh penjelasan bahwa dari 50 responden terdapat 16 responden dengan kategori tinggi (32\%) yang termasuk kedalam kategori tinggi hal ini dapat diartikan bahwa beberapa responden mempunyai keputusan yang tinggi untuk membeli kerudung merek deenay, karena mempunyai alasan yang baik mereka memakai kerudung deenay ., dengan memakai kerudung deenay konsumen marasa percaya diri dan mengambil keputusan untu membeli kerudung deenay. Masyarakat yang menggunakan kerudung merek deeenay mengagnggap bahwa deenay merupakan merek kerudung yang berkualitas.

Kemudian 32 responden dengan kategori sedang (64\%) dapat diartikan respoden tersebut mempunyai keputusan pembelian yang cukup, artinya responden sebenarnya mempunyai alas an yang cukup terhadap kualitas merek deenay, mereka mengangagp merek deenay merupakan kerudung yang bagus, ada 2 orang responden dengan kategori rendah (4\%), hal ini dapat diartikan mereka tertarik dengan merek deenay namun mereka terkendala dengan harga kerudung yang cukup mahal.

\section{Hasil Analisis Data}

\section{Analisis Regresi}

Analisis data penelitian yang digunakan untuk menguji hipotesis terdiri dari analisis regresi sederhana dan regresi berganda. Hasil analisis regresi sederhana adalah sebagai berikut:

Tabel 4.10

Hasil Analisis Regresi

\begin{tabular}{|c|c|c|c|c|c|c|}
\hline & Koefisien & & & & & \\
\hline & Regresi & & & & & \\
\hline Konstanta (a) & 18,502 & \multirow[b]{2}{*}{29,689} & \multirow[b]{2}{*}{4,04} & \multirow[b]{2}{*}{0,618} & \multirow[b]{2}{*}{0,328} & \multirow[b]{2}{*}{0,000} \\
\hline Citra merek (b) & 0,677 & & & & & \\
\hline
\end{tabular}

Tabel 4.11

Coefficients Regresi Linier Sederhana Untuk Pengaruh Citra Merek (Brand Image) Kerudung Deenay Terhadap Pengambilan Keputusan Pembelian Kerudung Deenay

\begin{tabular}{|c|c|c|c|c|c|c|}
\hline \multicolumn{2}{|l|}{ Mode } & \multicolumn{2}{|c|}{ Unstandardized } & Standardized & & \\
\hline \multicolumn{2}{|l|}{1} & \multicolumn{2}{|c|}{ Coefficients } & Coefficients & $\mathrm{t}$ & Sig. \\
\hline & & & Std. & & & Std. \\
\hline & & B & Error & Beta & B & Error \\
\hline 1 & (Constant) & 18,502 & 6,081 & & 3,043 & ,004 \\
\hline & Citra Merek & 677 & ,124 & ,618 & 5,449 & 000 \\
\hline
\end{tabular}

a Dependent Variable : Keputusan Pembelian 
Berdasarkan hasil analisis regresi tersebut, maka diperoleh persamaan regresi sebagai berikut: $\mathrm{Y}=18,502+0,677 \mathrm{X}$

Uji koefisien tersebut dilakukan dengan cara mengonsutasi harga $F_{\text {hitung }} 29,689>F_{\text {tabel }}(4,04)$ pada taraf signifikansi $5 \%$ dan $R_{\text {hitung }}=0,618>R_{(0.05)(49)}=0,231$, berarti koefisien tersebut signifikan. Dengan demikian, dapat diartikan bahwa citra merek sangat berpengaruh terhadap keputusan pembelian masyarakat dalam membeli kerudung merek Deenay. Tinggi maupun rendahnya kualitas citra merek Deenay sangat berpengaruh terhadap kepausan masyarakat dalam membelinya. Berdasarkan hasil perhitungan maka hipotesis yang menyatakan " pengaruh citra merek (brand image) terhadap pengambilan keputusan pembelian Kerudung Deenay pada Toko Gea Fashion Banjar sangat berpengaruh pada pengambilan keputusan pembelian merek kerudung Deenay pada Gea Fashion Banjar.

\section{Uji Koefisien Determinasi}

Besarnya pegaruh citra merek terhadap keputusan pembelian diketahui dengan cara nilai $\mathrm{R}=\left(\mathrm{r}^{2} \mathrm{x}\right.$ $100 \%$ ). Nilai $\mathrm{r}^{2}$ sebesar 0,328 sehingga besarnya pengaruh citra merek terhadap keputusan pembelian sebesar $38,2 \%$, sedangkan sisanya sebesar $61,8 \%$ dipengaruhi oleh faktor lain yang tidak masuk dalam variabel penelitian.

\section{Uji t}

Pada Uji t ini digunakan untuk mengetahui signifikansi variabel bebas yaitu citra merek (brand image) kerudung deenay terhadap variabel terikat yaitu keputusan pembelian kerudung deenay. Berdasarkan hasil analisis data, diperoleh nilai t hitung sebesar 5,449 dan t tabelnya sebesar 2,021 dengan tingkat signifiansi yang ditentukan 0,05 atau $5 \%$.

\section{Pembahasan}

\section{Citra Merek ( Brand Image ) Kerudung Deenay}

Citra merek merupakan sebuah kepercayaan masyarakat terhadap sebuah produk berdasarkan pengalaman yang telah mereka alami, yang didalamnya terdapat kelebihan dan kekurangan sebuah produk yang telah mereka gunakan.

Masyarakat akan terus mengingat tentang keunggulan dan keunikan sebuah produk, dan tidak menutup kemungkinan akan menyampaikan pengalaman mereka tentang citra merek tersebut kepada orang lain.

Bersadarkan tabel 4.1 yang menunjukkan bahwa dari 50 responden terdapat sebagain besar yang mneyatakan bahwa citra merek Deenay berkategori sedang dengan presentase $58 \%$. Data tersebut dapat diartikan bahwa citra merek deenay memperoleh citra yang baik di masyarakat dalam kesungguhan, kekuatan dan keunikan merek deenay. Merek deenay dianggap merek yang bagus dibandingkan dengan merek yang lain. Responden menggagap merek deenay mempunyai keunggulan dalam kualitas dan kredibilitas sehingga mampu menumbuhkan rasa percaya diri seseorang yang memakainya, namun yang menjadi kendala dalam keputusan pembelian adalah harga jual kerudung yang cukup mahal.

Citra merek kerudung deenay sudah mendapatkan rangking yang tinggi di masyarakat, hal ini dapat dilihat dari kepercayaan masyarakat yang telah menggunakan merek kerudung deenay, karena konsumen sudah percaya dan yakin pada merek tersebut maka konsumen terus mengambil keputusan pembelian yang berulang. Hal ini sejalan dengan pernyataan Tjiptono (2005:49) dalam (Dedhy Pradana, 2017) yang menyatakan bahwa citra merek adalah deskripsi tentang asosiasi dan keyakinan konsumen terhadap merek tertentu.

\section{Keputusan Pembelian Kerudung Deenay}

Keputusan pembelian merupakan sebuah tindakan yang dilakukan oleh konsumen untuk membeli sebuah produk yang mereka inginkan sesuai dengan keunggulan atau kelebihan dari produk yang mereka minati atau produk tersebut memiliki brand image yang baik.

Berdasarkan hasil penelitian, dari 50 orang responden sebagain besar berkategori sedang $64 \%$ hal tersebut diartikan bahwa beberapa responden mempunyau keputusan pembelian yang tinggi, hal ini dikarenakan beberapa responden tersebut mengambil keputusan untuk membeli kerudung deenay karena masyarakat mempunyai anggapan bahwa merek deenay adalah merek kerudung yang baik dan kualaitas, 
dengan memakai kerudung deenay masyarakat akan merasa percaya diri selain dari pengaruh lingkungan yang membuat masyarakat membuat keputusan untuk membeli kerudung deenay.

Berdasarkan hasil penelitian tersebut konsumen yang mempercayai kerudung deenay ini dikarenakan kerudung deenay mempunyai kualitas yang baik, sesuai dengan harapan konsumen. Meskipun harga kerudung Deenay relatif tinggi namun karena keunggulan, kekuatan dan keunikan merek deenay tersebut konsumen tetap melakukan keputusan pembeliannya pada kerudung deenay. Bagi konsumen harga yang tinggi bukan lagi merupakan masalah ketika mereka telah memiliki kepercayaan yang tinggi terhadap kualitas merek tertentu atau citra merek sebuah produk.

Pernyataan ini sejalan dengan Suharno (2010:96) dalam (Fatih Imantoro, 2018) yang menyatakan keputusan pembelian adalah tahap dimana pembeli telah menentukan pilihannya dan melakukan pembelian produk, serta mengkonsumsinya. Hal ini berkaitan dalam usahanya memenuhi kebutuhan dengan tahap yang dilibatkan dalam mengevaluasi, memperoleh dan menggunakan produk.

\section{Pengaruh Citra Merek (Brand Image) Terhadap Keputusan Pembelian Kerudung Deenay pada Gea Fashion Banjar}

Berdasarkan hasil penelitian diatas diperoleh $\mathrm{F}_{\text {hitung }} 29,689>\mathrm{F}$ tabel $(4,04)$ dan $\mathrm{R}_{\text {hitung }}=0,618>$ $\mathbf{R}_{(0.05)(49)}=0,231$, hasil tersebut dapat diartikan bahwa ada pengaruh citra merek (brand image) terhadap keputusan pembelian Kerudung Deenay pada Gea Fashion Banjar. Pengaruh tersebut diartikan bahwa citra merek (brand image) merupakan salah satu faktor yang cukup mempengaruhi keputusan pembelian, dengan citra merek (brand image) yang baik maka masyarakat akan lebih percaya pada citra merek (brand image) sehingga banyak masyarakat yang memilih merek tersebut.

Masyarakat akan melakukan keputusan pembelian dengan berbagai macam pertimbangan, ada faktor-faktor yang dapat mempengaruhi masyarakat untuk melakukan pembelian. Kerudung deenay sudah mempunyai citra merek yang positif di masyarakat sehingga banyak orang yang tertarik dan memilih membeli kerudung deenay. Meskipun harga jual kerudung deenay tergolong cukup mahal namun konsumen merasa puas dengan kualiats yang dimiliki oleh produk kerudung deenay, salah satunya adalah toko Gea Fashion Banjar.

\section{KESIMPULAN}

Berdasarkan hasil penelitian dan pembahasan yang telah diuraikan, maka dapat ditarik kesimpulan sebagai berikut:

1. Citra merek (brand image) memiliki pengaruh yang signifikan terhadap pengambilan keputusan pembelian kerudung deenay. Nilai signifikansi ini diperoleh dari $F_{\text {hitung }} 29,689$ dengan signifikansinya 0,000 dengan $\quad F_{\text {tabel }}(4,04)$ pada taraf signifikansi nya 0,05 dan taraf koefisien determinasi $\left(r^{2}\right)$ atau $R$ square dipeoleh sebesar 0,328 , sehingga besarnya pengaruh sebesar $38,2 \%$, sedangkan sisanya sebesar $61,8 \%$ dipengaruhi oleh factor lain yang tidak masuk dalam variable penelitian ini. Hasil tersebut dapat diartikan bahwa citra merek (brand image) kerudung deenay menjadi salah satu faktor keputusan pembelian Kerudung Deenay pada Gea Fashion Banjar.

2. Citra merek (brand image) Deenay sudah mendapatkan kepercayaan yang tinggi dimasyarakat, karena produk kerudung ini mempunyai kelebihan dan keunggulan, kekuatan serta keunikan produk dari produk lainnya yang sejenis.

3. Keputusan pembelian yang dilakukan konsumen untuk membeli produk kerudung deenay selain karena pengaruh citra merek produk, namun juga dipengaruhi oleh unsur sosial, faktor budaya, faktor pribadi dan faktor psikologis. Dari faktor-faktor tersebut yang sangat tinggi pengaruhnya yaitu unsur sosial.

\section{IMPLIKASI}

Berdasarkan kesimpulan diatas maka implikasi dalam penelitian adalah sebagai berikut:

1. Citra Merek (Brand Image) berpengaruh terhadap keputusan pembelian, dengan demikian perusahaan harus tetap menjaga dan meningkatkan brand image kerudung Deenay di masyarakat, supaya keputusan pembelian untuk kerudung deenay terus meningkat dimasa yang akan datang. 
2. Penelitian ini dapat dikembangkan oleh peneliti berikutnya dengan variable yang berbeda yang berhubungan dengan citra merek dan keputusan pembelian

3. Sebagai referensi untuk pengembangan ilmu pengetahuan dalam bidang administrasi bisnis.

\section{DAFTAR PUSTAKA}

Dedhy Pradana, S. H. (2017). Pengaruh Harga Kualitas Produk dan citra merek Brand Image terhadap keputusan pembelian motor. Kinerja, 18.

Fatih Imantoro, S. S. (2018). Pengaruh Citra Merek,Iklan, dan Cita Rasa terhadap Keputusan Pembelian (survei terhadap Konsumen Mi Instan Merek Indomie di Wilayah Um Al-Hamam Riyadh). Jurnal Administrasi Bisnis (JAB), 180.

Fristiana, D. A. (2012). Pengaruh Citra Merek dan Harga terhadap Keputusan Pembelian pada rmai swalayan Peterongan Semarang. Jurnal Ilmu Administrasi Bisnis, 3-4.

Halimah. (2015). Pengaruh Brand Image Rokok Dunhill Terhadap Keputusan Pembelian Di Kota Pontianak. JURNAL, 4.

Sugiyono. (2014). Metode Penelitian Kuantitatif Kualitatif dan $R \& D$. Bandung: Alfabeta.

Tingkir, C. F. (2014). Pengaruh Identitas Merek terhadap Loyalitas Merek Melalui Citra Merek dan Kepercayaan Merek Toyota. Jurnal Manajemen Pemasaran, 63.

Zulganef. (2013). Metode Penelitian Sosial \& Bisnis. Yogyakarta: Graha Ilmu. 